\title{
Evaluation of Different Best Management Practices for Erosion Control on Machine Operating Trails
}

\author{
Ahmad Solgi, Ramin Naghdi, Eric R. Labelle, Farshad Keivan Behjou, Vahid Hemmati
}

\begin{abstract}
Ground-based mechanized forest operations often lead to increased runoff and soil loss on unbound forest roads and machine operating trails, which in turn can impede the technical trafficability of machines and cause negative impacts on the environment. The aim of this study was to evaluate the effectiveness of three Best Management Practice (BMP) treatments used to control erosion occurring on machine operating trails. The treatments included water bar, water bar and hardwood brush (H-brush), and water bar and softwood brush (S-brush). For a more comprehensive assessment of both brush treatments, two levels of brush thickness were tested; $0.5 \mathrm{~m}$ and $1.0 \mathrm{~m}$. Results indicate that the most effective BMP treatments were the water bar and softwood brush followed by the water bar and hardwood brush and finally the least effective was the water bar. The average runoff rates and soil loss from the machine operating trails with the water bar treatment (52.64 l per plot, $8.49 \mathrm{~g} \mathrm{~m}^{-2}$ ) were higher than runoff and soil loss at the trails protected with hardwood brush (23.75 l per plot, $\left.4.5 \mathrm{~g} \mathrm{~m}^{-2}\right)$, and the trails protected by the hardwood brush had higher runoff and soil loss compared to trails covered by softwood brush (15.83 l per plot, $2.98 \mathrm{~g} \mathrm{~m}^{-2}$ ). Furthermore, results of this study showed that regardless of the treatment, the amount of runoff and soil loss decreased consistently as the thickness of the brush mat increased. Overall, erosion control techniques similar to either H-brush or S-brush that provide direct soil coverage should be used for erosion control, and final selection should be based on costs, availability of material, or landowner objectives.
\end{abstract}

Keywords: runoff; brush, soil disturbance, soil protection, water bar, forest machines

\section{Introduction}

Forest roads and machine operating trails can cause significant increases in surface runoff and sediment yield, especially when bare soils are exposed to high machine traffic frequency or when the bearing capacity of a soil is exceeded and rutting occurs (Swift and Burns 1999, McBroom et al. 2008, Solgi et al. 2014). Therefore, most forestry Best Management Practices (BMPs) were developed with a focus on controlling erosion associated with transportation networks, including roads, wood landings, machine operating trails, and stream crossings (Aust and Blinn 2004, Anderson and Lockaby 2011). Typical BMPs for roads, machine operating trails, and landings include proper planning and location, control of longitudinal and transverse gradients, use of buffer areas, control of water, surfacing, road or trail closure to minimize soil disturbance, and revegetation following harvesting (Swift 1985, Aust and Blinn 2004, Shepard 2006, Ice et al. 2010, Akbarimehr and Naghdi 2012a). These practices are designed to achieve two significant objectives: control erosion at a harvest site and minimize the delivery of sediment and pollutants to natural drainage lines (Wallbrink and Croke 2002).

Creation of water diversion structures to reduce runoff generation and sediment yield such as water bars can be a very effective sediment control method for limiting sediment delivery to adjacent areas (Wallbrink and Croke 2002). Water bars can be applied where other BMPs are less effective in controlling soil erosion and sediment discharge because of soil condition, steep slope, and long slope length. In addition, water bars can be effectively adopted where the rainfall amount is considerable. However, the utilization 
of logging residues (brush) obtained during the processing phase of harvested trees in combination with water bars can be a successful combination to minimize soil erosion. Litschert and MacDonald (2009) recommended increasing water bar frequency and surface roughness on machine operating trails (e.g., litter, brush, and woody debris) in order to minimize the amount of sediment deposited into nearby streams.

Traffic on machine operating trails can alter hillslope hydrology by inducing compaction, which created less permeable soil surfaces that result in decreased infiltration and increased overland water flow, soil erosion, and sedimentation during rain events (Croke and Mockler 2001, Croke et al. 2001, Grace 2005, Jackson et al. 2002). The magnitude of environmental impacts caused by machine traffic is related to terrain gradient (Akbarimehr and Naghdi 2012a), traffic frequency of forest machines (Labelle and Jaeger 2011, Solgi et al. 2014), vegetation cover (Cerdà 2007, Lee et al. 2013), applied loads (Battiato et al. 2013), seasonality and rainfall intensity (Martínez-Zavala et al. 2008), soil texture (Pinard et al. 2000, Croke et al. 2001), and the time since construction (Fu et al. 2010). Morgan (1986) reported that soil erosion is affected by many factors, among them terrain gradient and vegetation cover have an important role on soil erosion.

Undisturbed area has minimal erosion and sedimentation due to good surface cover of trees and understory, which protects the soil surface from damaging storm energy (Grace 2002). Solgi et al. (2014) reported that, on control (undisturbed) plots, even the largest storm events did not generate runoff and sediment. Forest floor, woody debris, and brush increased surface roughness and provided dissipation of the energy associated with raindrop impact, which can dislodge soil particles (Wischmeier and Smith 1958).

Within a context of soil erosion on trails trafficked by forest machines, the specific objectives of this study were to:

$\Rightarrow$ evaluate the erosion control efficacy of three different machine operating trail BMPs (water bar only, water bar and hardwood brush, and water bar and softwood brush);

$\Rightarrow$ analyze the effectiveness of two brush mat thicknesses $(0.5 \mathrm{~m}$ and $1.0 \mathrm{~m})$ on the relative change of surface runoff and sediment yield.

\section{Material and Methods}

\subsection{Study Area}

This research was conducted from May to July 2016 in Shenrood forest, Guilan province, northern Iran be- tween $36^{\circ} 13^{\prime} \mathrm{N}$ and $36^{\circ} 15^{\prime} \mathrm{N}$ and $53^{\circ} 10^{\prime} \mathrm{E}$ and $53^{\circ} 15^{\prime} \mathrm{E}$. The area is predominantly covered by oriental beech (Fagus orientalis Lipsky) and common hornbeam (Carpinus betulus L.) stands. Brown forest soil was formed on unconsolidated limestone with a moderately deep profile. The soil was classified as Eutric Cambisols (FAO/UNESCO 1990), and Typic Eutrudepts (USDA Soil Taxonomy 1998). Soil collected at the research site from the $0-10 \mathrm{~cm}$ layer, was analyzed using the Bouyoucos hydrometer method and the texture was determined to be clay loam with a particle size distribution of $37 \%$ clay ( $<0.002 \mathrm{~mm}$ size), $38 \%$ silt $(0.002-0.05 \mathrm{~mm})$, and $25 \%$ sand $(0.05-2 \mathrm{~mm})$ along the machine operating trail. The average thickness of soil to the bedrock ranged from $60-70 \mathrm{~cm}$. The elevation of the study sites ranged between approximately $900-1100 \mathrm{~m}$ above sea level with a northern aspect. The average annual rainfall recorded at the closest national weather station, located $20 \mathrm{~km}$ from the research area, is $1130 \mathrm{~mm}$ with a maximum mean monthly rainfall of $140 \mathrm{~mm}$ in October and a minimum rainfall of $25 \mathrm{~mm}$ in August. Based on historic weather data of the previous 50 years, the mean annual temperature is $16^{\circ} \mathrm{C}$, with lowest temperatures occurring in February. At the time of ground-based skidding, weather conditions were dry and warm with an average gravimetric soil moisture content of $19 \%$. The soil had not been driven on before the experiment.

Harvesting operations were performed by chainsaws (felling and processing), followed by transportation of processed logs from the forest stand to roadside landings by a rubber-tired Timberjack $450 \mathrm{C}$ cable skidder. Due to the absence of trail protective treatments during trafficking with the cable skidder, no forest floor or litter material remained after skidding was completed.

\subsection{Experimental Design}

This study evaluated three BMP treatments used for erosion control on machine operating trails in the Hyrcanian forest, northern Iran. Prior to establishing the field test plots, ground-based skidding operations were performed over the target machine operating trails where machine traffic frequency was held constant at 21 loaded passes. BMP treatments consisted of water bar only (water bar), water bar and hardwood brush (H-brush), and water bar and softwood brush (S-brush). They were established in field plots on three machine operating trails with longitudinal gradients varying between $15-18 \%$ (Fig. 1). Both water bar and brush treatments for hardwood and softwood mats were further divided into two brush thickness levels defined as $0.5 \mathrm{~m}$ (light) and $1.0 \mathrm{~m}$ (heavy). Because of 


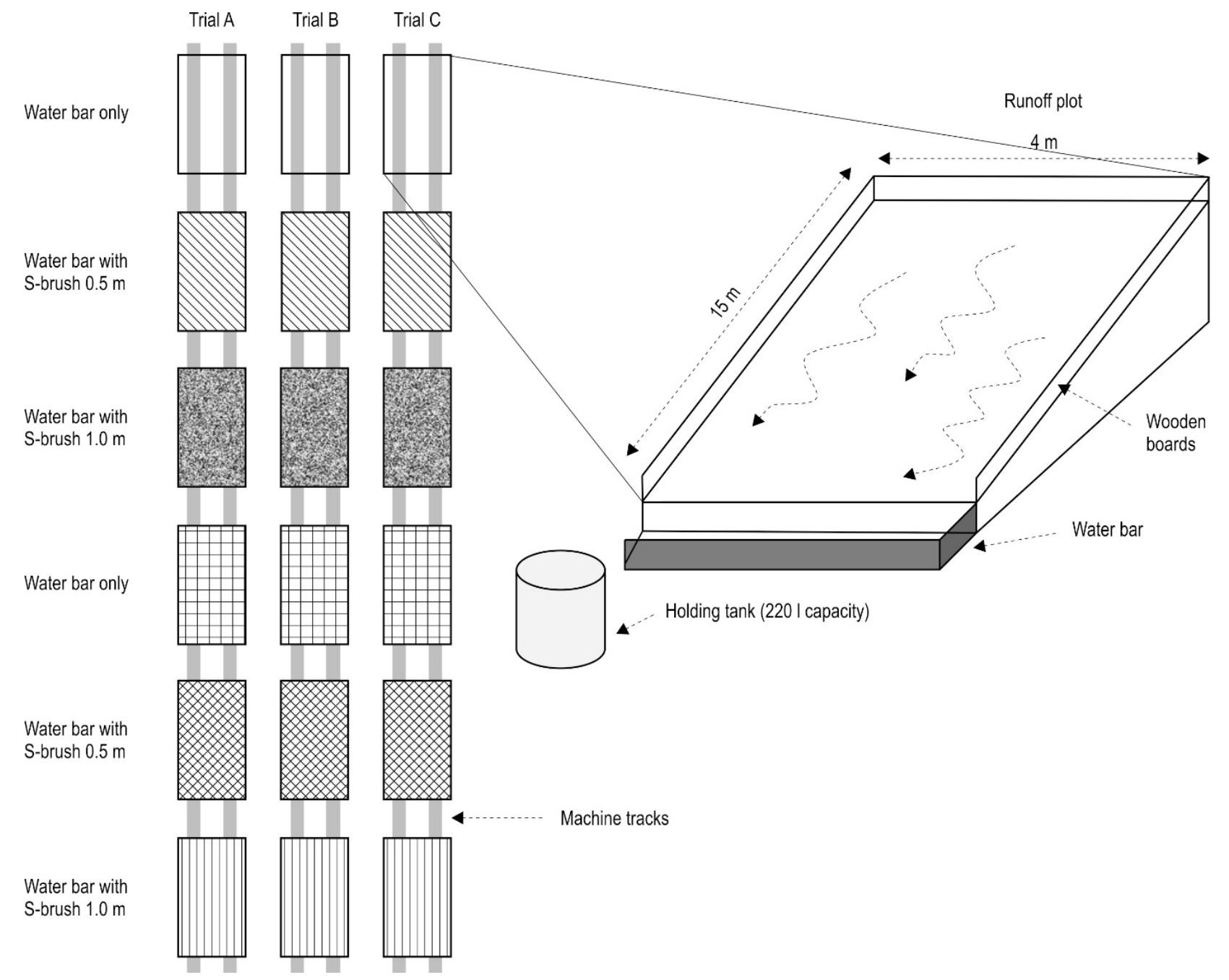

Fig. 1 Experimental layout of field trials

the length of trail needed to establish all treatments, along with the associated possibilities of varying soil properties with extended spatial distribution, the water bar treatment was tested on two plots per machine operating trails. One plot was located with the hardwood plots and the other water bar plot was located with the softwood plots (Fig. 1). Therefore, a total of 18 runoff plots were installed that included a total of six combinations derived from three BMP treatments (water bar, H-brush, and S-brush) and two levels of brush mat thickness $(0.5 \mathrm{~m}$ and $1.0 \mathrm{~m})$ tested in triplicates. The H-brush and S-brush treatments consisted of the water bar plus an application of piled hardwood and softwood branches, which ranged from 2 to $15 \mathrm{~cm}$ in diameter at the large end and from 1.0 to $2.5 \mathrm{~m}$ in length. Hardwood brush was composed of branches of beech trees whereas softwood brush comprised branches of pine trees. To construct the needed brush mats, branches originating from nearby felling operations were piled perpendicular to the axis of travel in each treatment plot until the target thickness $(0.5 \mathrm{~m}$ or $1.0 \mathrm{~m}$ ) was reached. Subsequently, the newly constructed brush mats were compacted by a John Deere $450 \mathrm{E}$ bulldozer to consolidate the branches, thus ensuring adequate ground contact (Wade et al. 2012).

Each treatment plot was $15 \mathrm{~m}$ long and $4 \mathrm{~m}$ wide, with a $5 \mathrm{~m}$ buffer zone between each plot to avoid interactions. Treatment plots were surrounded by wooden boards that were $30 \mathrm{~cm}$ in height and inserted $10 \mathrm{~cm}$ deep into the soil to control surface water movement from the inside to the outside of the plot area and vice-versa (Solgi et al. 2014). A water bar was constructed on the lower elevation side of each treatment plot so that all surface water runoff from inside the area could be collected in a holding tank with a capacity of 220 liters (Fig. 1). The inclination of a water bar 
is important for slowing and diverting water from the machine operating trail and a slope of $2-4 \%$ is ideal. Therefore, water bars were installed with a $3 \%$ outslope at a depth of 30-35 $\mathrm{cm}$ from the soil surface.

The sediment concentration within each treatment plot was determined after thorough mixing and bringing all the sediments into suspension and extracting a subsample of 1 liter of collected runoff material, and then using the drying and weighing method (Sadeghi et al. 2007). A collecting channel, made of sheet metal and covered with plastic or sheet metal to prevent direct entry of rainfall, was positioned at the downslope end of each plot. The volume of the surface runoff was computed after measuring the height of the water in the holding tanks. Samples were taken to the laboratory where the sediment was filtered and oven-dried at $105^{\circ} \mathrm{C}$ until a constant mass was obtained. (i.e., the drying and weighing method). For each rainfall event, we computed runoff volume and sediment loss from each plot. Holding tanks were emptied and cleaned after each rainfall and sampling event.

\subsection{Statistical Analysis}

One-way and two-way analysis of variances (ANOVA's) were used to assess the significance of observed differences in average runoff and soil loss in runoff plots from nine runoff events as a function of BMP treatments on different brush mat thickness and their interaction effects, respectively, at a significance level of $\alpha \leq 0.05$. Tukey's $H S D$ test was used to compare the amount of runoff and soil loss among the three tested BMP treatments (main effects). All statistical calculations were performed in SPSS version 11.5.

\section{Results and Discussion}

Both hardwood and softwood branches used to create the brush mats were collected at the end of April 2016 from the harvested stands and had water content (percent of green mass) varying between 35 and $46 \%$. The results showed that runoff rates and soil loss were significantly affected by BMP treatments as well as brush mat thickness, but the interactions of BMP treatment $\times$ mat thickness was not significant (Table 1).

The BMP treatments comprised of hardwood and softwood brush had significantly lower runoff and erosion rates compared to the water bar treatment (Table 2). Wade et al. (2012) conducted a similar study on machine operating trails and also reported the benefits of using H-brush and S-brush treatments to reduce erosion. When comparing both brush compositions (hardwood and softwood), results indicate that
Table $1 P$ values based on analysis of variance of the effects of BMP treatments, brush mat thickness and the interaction between BMP treatments and brush mat thickness for runoff volume (liters) and soil loss $\left(\mathrm{g} \mathrm{m}^{-2}\right)$

\begin{tabular}{|l|c|c|c|}
\hline \multirow{2}{*}{\multicolumn{1}{|c|}{ Source of variable }} & \multirow{2}{*}{ d.f. } & \multicolumn{2}{c|}{$p$ Values $^{*}$} \\
\cline { 3 - 4 } & & Runoff & Soil loss \\
\hline BMP treatment & 2 & $\leq 0.005$ & $\leq 0.005$ \\
\hline Mat thickness & 1 & $\leq 0.005$ & $\leq 0.005$ \\
\hline BMP treatment $\times$ Mat thickness & 2 & 0.154 & 0.563 \\
\hline
\end{tabular}

${ }^{*} P$ values less than 0.05 are given in bold

within a respective thickness level, softwood brush performed better through a lower runoff and erosion rate. When combining results from the two tested brush thickness levels, the average runoff rates and soil loss from the machine operating trails with the S-brush treatment (15.83 1 per plot, $2.98 \mathrm{~g} \mathrm{~m}^{-2}$ ) were lower than the values measured at the trails with the H-brush treatment (23.75 1 per plot, $4.5 \mathrm{~g} \mathrm{~m}^{-2}$ ), whereas the trails with the $\mathrm{H}$-brush treatment had lower runoff and soil loss than the trail with the water bar treatment (52.64 l per plot, $8.49 \mathrm{~g} \mathrm{~m}^{-2}$ ). This is in agreement with findings reported by Sawyers et al. (2012) and Wade et al. (2012). Sawyers et al. (2012) also evaluated BMP treatments for machine operating trails and found the highest erosion rate with water bar only and lowest erosion rate with S-brush treatment. Wade et al. (2012) evaluated five BMP treatments (water bar only, water bar and grass seed (grass), water bar, grass seed, and straw mulch (mulch), water bar and piled hardwood brush, and water bar and piled softwood brush) on

Table 2 Means ( \pm std) of runoff volume (liters) and soil loss $\left(\mathrm{g} \mathrm{m}^{-2}\right)$ from different BMP treatments and brush mat thicknesses. H-brush, hardwood brush; S-brush, softwood brush

\begin{tabular}{|c|c|c|c|c|}
\hline \multirow{2}{*}{$\begin{array}{c}\text { Mat thickness } \\
m\end{array}$} & \multicolumn{3}{|c|}{ BMP treatment } \\
\cline { 2 - 5 } & Water bar & H-brush & S-brush \\
\hline \multirow{2}{*}{ Runoff } & 0.5 & $52.64 \pm 5.1^{\mathrm{Aa}}$ & $30.93 \pm 3.6^{\mathrm{Ba}}$ & $22.14 \pm 2.7^{\mathrm{Ca}}$ \\
\cline { 2 - 5 } & 1 & $52.64 \pm 5.1^{\mathrm{Aa}}$ & $16.57 \pm 2.4^{\mathrm{Bb}}$ & $9.53 \pm 1.9^{\mathrm{Cb}}$ \\
\hline \multirow{2}{*}{ Soil loss } & 0.5 & $8.49 \pm 1.4^{\mathrm{Aa}}$ & $5.64 \pm 0.9^{\mathrm{Ba}}$ & $4.03 \pm 0.6^{\mathrm{Ca}}$ \\
\cline { 2 - 5 } & 1 & $8.49 \pm 1.4^{\mathrm{Aa}}$ & $3.37 \pm 0.7^{\mathrm{Bb}}$ & $1.94 \pm 0.4^{\mathrm{Cb}}$ \\
\hline
\end{tabular}

Note: Different letters within each treatment show significant differences $(P<0.05)$ Capital case letters refer to the comparisons between the three BMP treatments for each mat thickness (row)

Lower case letters refer to the comparison between the two mat thickness levels in each BMP treatment separately (column) 
Table 3 Average reduction in runoff volume and soil loss (\%) compared to water bar treatment. H-brush, hardwood brush; S-brush, softwood brush

\begin{tabular}{|l|c|c|c|}
\hline \multirow{2}{*}{} & \multirow{2}{*}{$\begin{array}{c}\text { Mat thickness } \\
\mathrm{m}\end{array}$} & \multicolumn{2}{|c|}{ BMP treatment } \\
\cline { 3 - 4 } & 0.5 & H-brush & S-brush \\
\hline \multirow{3}{*}{ Runoff } & 1 & 68.5 & 57.9 \\
\cline { 2 - 4 } & 0.5 & 33.6 & 81.9 \\
\hline \multirow{2}{*}{ Soil loss } & 1 & 60.3 & 52.5 \\
\cline { 2 - 4 } & & & 77.1 \\
\hline
\end{tabular}

machine operating trails in the Piedmont of Virginia and reported the highest erosion rate with water bar only and lowest erosion rate with the mulch treatment.

In our study, the H-brush and S-brush treatment reduced soil erosion (soil loss) by $60 \%$ and $77 \%$, respectively when compared to the water bar treatment (Table 3). Sawyers et al. (2012) concluded that sediment production from surface erosion was reduced by $86 \%$ when a mulch treatment was applied to machine operating trails. Wade et al. (2012) reported $93 \%$ and $96 \%$ reductions in erosion when $\mathrm{H}$-brush and S-brush treatments were applied to machine operating trails as compared to the water bar only. Grushecky et al. (2009) evaluated the effectiveness of fiber mats on soil erosion from machine operating trails as compared to water bars and seed and reported that the cover provided by the fiber mats reduced erosion by $88 \%$. Our S-brush treatment provided partly similar erosion control results to those obtained with the fiber mats used by Grushecky et al. (2009), but the fiber mats would be considerably more expensive than brush, particularly if no biomass operations are intended for a harvest site.

The H-brush and S-brush treatments provided immediate surface cover of the treatment plot thereby protecting the bare soil from raindrop impacts, which minimized loosening of soil particles and reduced the velocity of surface runoff causing deposition of sediment. Jordán et al. (2010) reported that the BMP treatments increased the surface roughness and the interception of raindrops, which in turn delayed runoff generation. Puustinen et al. (2005) found that mulching contributed to decrease runoff flow and enhance water infiltration.

Our results showed that for a respective thickness level, S-brush treatment outperformed the H-brush treatment by providing better erosion control. Findings by Sawyers et al. (2012) and Wade et al. (2012) also support the effectiveness of S-brush mat for erosion control. Within a treatment plot, the S-brush treatment had higher percentage of ground cover than what was visually noticed for the $\mathrm{H}$-brush treatment. This likely occurred since the softwood brush was more easily broken apart by the bulldozer traffic than the hardwood brush, and since S-brush was also more consistent in leaf area as compared to H-brush. Those two main factors resulted in softwood brush having a more uniform contact with the soil, thus providing better overall coverage (Wade et al. 2012, Labelle and Jaeger 2015).

Irrespective of brush species composition, amounts of runoff and soil loss decreased consistently when mat thickness was increased (Table 2). With a lower mat thickness, the average runoff rates from the $\mathrm{H}$ brush and S-brush treatments were reduced by $41.2 \%$ and $57.9 \%$, respectively, when compared to the water bar treatment, while the reductions for the highest mat thickness were $68.5 \%$ and $81.9 \%$, respectively (Table 3). Similarly, with the lower mat thickness, the average soil loss from the $\mathrm{H}$-brush and S-brush treatments was reduced by $33.6 \%$ and $52.5 \%$, respectively, when compared to the water bar treatment, while the reductions for the highest mat thickness were $60.3 \%$ and $77.1 \%$, respectively (Table 3). The thickness of a brush mat placed on the soil can strongly affect runoff dynamics, and reduce runoff generation and soil loss (Rees et al. 2002, Findeling et al. 2003). Our findings support the use of combined water bars and brush mats, particularly the thicker $1.0 \mathrm{~m}$ mats, for effective protection against runoff and soil loss.

\section{Conclusions}

Research results indicate that forestry BMPs can effectively reduce sediment from ground-based mechanized forest operations. On relatively steep machine operating trails (15-18\% longitudinal gradient), where soil erosion rates are normally very high, water bars alone may not provide sufficient erosion control. In this case, BMP techniques that enhance soil stability should be considered in combination with water bars. As such, the combination of the tested brush treatments with water bars were effective techniques in controlling erosion on machine operating trails. The effectiveness of the brush treatments are primarily linked to their added ground cover, which stabilizes the soil by providing protection from rainfall impact and reduction in overland flow velocity by increasing the surface roughness. Within test conditions and for a respective thickness level, softwood brush seemed to be more effective than hardwood brush.

Erosion rates were highest directly following skidding operations and the construction of the machine 
operating trail. Since soils are highly susceptible to erosion after soil disturbance, especially during spring months, which generally experience higher intensity rain events, BMPs should be applied immediately after skidding is completed. The tested brush and water bar combination treatments offered the best protection against runoff and erosion rates. BMPs that provide sufficient soil cover, such as the brush treatments, should be used during these critical periods to prolong the technical performance of the trails for future use during re-entry and protect the surrounding environment from high erosion rates.

\section{References}

Akbarimehr, M., Naghdi, R., 2012a: Determination of most appropriate distance between water diversions on skid trails in the mountainous forest, north of Iran. Catena 88(1): 68-72. https://doi.org/10.1016/j.catena.2011.08.005

Akbarimehr, M., Naghdi, R., 2012b: Assessing the relationship of slope and runoff volume on skid trails (Case study: Nav 3 district). Journal of Forest Science 58(8): 357-362.

Anderson, C.J., Lockaby, B.G., 2011: Research gaps related to forest management and stream sediment in the United States. Environmental Management 47(2): 303-313. https:// doi.org/10.1007/s00267-010-9604-1

Aust, W.M., Blinn, C.R., 2004: Forestry best management practices for timber harvesting and site preparation in the eastern United States: An overview of water quality and productivity research during the past 20 years (1982-2002). Water, Air, and Soil Pollution: Focus 4(1): 5-36. https://doi. org/10.1023/B:WAFO.0000012828.33069.f6

Battiato, A., Diserens, E., Laloui, L., Sartori, L., 2013: A mechanistic approach to topsoil damage due to slip of tractor tyres. Journal of Agricultural Science and Application 2(3): 160-168.

Cerdà, A., 2007: Soil water erosion on road embankments in eastern Spain. Science of the Total Environment 378(1-2): 151-155. https://doi.org/10.1016/j.scitotenv.2007.01.041

Copstead, R.L., Johansen, D.K., Moll, J., 2003: Water/Road Interaction: Introduction to Surface Drains. Department of Agriculture Forest Service Technology and Development Program 9877 1806-SDTDC, San Dimas, USA, 23 p.

Croke, J., Mockler, S., 2001: Gully initiation and road-tostream linkage in a forested catchment, southeastern Australia. Earth Surface Processes Landforms 26(2): 205-217. https://doi.org/10.1002/1096-9837(200102)26:2<205::AIDESP168>3.0.CO;2-G

Croke, J., Hairsine, P., Fogarty, P., 2001: Soil recovery from track construction and harvesting changes in surface infiltration, erosion and delivery rates with time. Forest Ecology and Management 143(1-3): 3-12. https://doi.org/10.1016/ S0378-1127(00)00500-4
FAO/UNESCO, 1990: Soil map of the world, revised legend. FAO World Soil Resources Report 60, Isric, Wageninen, ISBN 90-6672-057-3, 75 p.

Findeling, A., Ruy, S., Scopel, E., 2003: Modeling the effects of a partial residue mulch on runoff using a physically based approach. Journal of Hydrology 275(1-2): 49-66. https://doi. org/10.1016/S0022-1694(03)00021-0

Fu, B., Newham, L.T.H., Ramos-Scharron, C.E., 2010: A review of surface erosion and sediment delivery models for unsealed roads. Environmental Modelling and Software 25(1): 1-14. https://doi.org/10.1016/j.envsoft.2009.07.013

Grace, J.M., 2002: Effectiveness of vegetation in erosion control from forest road sideslopes. Transactions of ASAE 45(3): 681-685. https://doi: 10.13031/2013.8832

Grace, J.M., 2005: Forest operations and water quality in the South. Transactions of ASAE 48(2): 871-880. https:// doi: $10.13031 / 2013.18295$

Grushecky, S.T., Spong, B.D., Mcgill, D.W., Edwards, J.W., 2009: Reducing sediments from skid roads in West Virginia using fiber mats. Northern Journal of Applied Forestry 26(3): 118-121. https://doi.org/10.1093/njaf/26.3.118

Ice, G.G., Schilling, E., Vowell, J., 2010: Trends for forestry best management practices implementation. Journal of Forestry 108(6): 267-273. https://doi.org/10.1093/jof/108.6.267

Jackson, S.M., Fredricksen, T.S., Malcolm, J.R., 2002: Area disturbed and residual stand damage following logging in a Bolivian tropical forest. Forest Ecology and Management 166(1-3): 271-283. https://doi.org/10.1016/S03781127(01)00681-8

Jordán, A., Zavala, L.M., Gil, J., 2010: Effects of mulching on soil physical properties and runoff under semi-arid conditions in southern Spain. Catena 81(1): 77-85. https://doi. org/10.1016/j.catena.2010.01.007

Kalra, Y.P., Maynard, D.G., 1991. Methods and manual for forest soil and plant analysis. Information Report NOR-X319E, Forestry Canada, Northwest Region, Northern Forestry Centre, Edmonton, Alberta, Canada, 116 p.

Labelle, E.R., Jaeger, D., 2011: Soil compaction caused by cut-to-length forest operations and possible short-term natural rehabilitation of soil density. Soil Science Society of American Journal 75(6): 2314-2329.

Labelle, E.R., Jaeger, D., 2015: Assessing the ability of hardwood and softwood brush mats to distribute applied loads. Croatian Journal of Forest Engineering 36(2): 227-242.

Lee, J.W., Park, C.M., Rhee, H., 2013: Revegetation of decomposed granite road cuts in Korea: developing digger, evaluating cost effectiveness, and determining dimensions of drilling holes, revegetation species, and mulching treatment. Land Degradation and Development 24(6): 591-604. https:// doi.org/10.1002/ldr.2248

Litschert, S.E., MacDonald, L.H., 2009: Frequency and characteristics of sediment delivery pathways from forest harvest 
units to streams. Forest Ecology and Management 259(2): 143-150. https://doi.org/10.1016/j.foreco.2009.09.038

Martínez-Zavala, L., Jordán López, A., Bellinfante, N., 2008: Seasonal variability of runoff and soil loss on forest road backslopes under simulated rainfall. Catena 74(1): 73-79. https://doi.org/10.1016/j.catena.2008.03.006

McBroom, M.W., Beasley, R.S., Chang, M., Ice, G.G., 2008: Water quality effects of clearcut harvesting and forest fertilization with best management practices. Journal of Environmental Quality 37(1): 114-124. https:/doi:10.2134/ jeq2006.0552

Miller, R., 2006: The Water Bar - Water Quality Update for Loggers and Other Forestry Professionals. Serving Northwest North Carolina, N.C. Division of Forest Resources, North Carolina, USA, 2 p.

Morgan, R.P.C., 1986: Soil erosion and conservation. Longman Group, Harlow and J. Wiley \&Sons, New York, USA, ISBN 0-582-24492-7, 198 p.

Puustinen, M., Koskiaho, J., Peltonen, K., 2005: Influence of cultivation methods on suspended solids and phosphorus concentrations in surface runoff on clayey sloped fields in boreal climate. Agriculture, Ecosystems, and Environment 105(4): 565-579. https://doi.org/10.1016/j.agee.2004.08.005

Rees, H.W., Chow, T.L., Loro, P.J., Lovoie, J., Monteith, J.O., Blaauw, A., 2002: Hay mulching to reduce runoff and soil loss under intensive potato production in Northwestern New Brunswick, Canada. Canadian Journal of Soil Science 82(2): 249-258. https://doi.org/10.4141/S01-055

Sadeghi, S.H.R., Ghaderi Vangah, B., Safaeeian, N.A., 2007: Comparison between effects of open grazing and manual harvesting of cultivated summer rangelands of northern Iran on in filtration, runoff and sediment yield. Land Degradation and Development 18(6): 608-620. https://doi.org/10.1002/ ldr.799
Sawyers, B.C., Bolding, M.C., Aust, W.M., Lakel III, W.A., 2012: Effectiveness and Implementation Costs of Overland Skid Trail Closure Techniques in the Virginia Piedmont. Journal of Soil and Water Conservation 67(4): 300-310. https://doi.org/10.2489/jswc.67.4.300

Shepard, J.P., 2006: Water quality protection in bioenergy production: The US system of forestry best management practices. Biomass and Bioenergy 30(4): 378-384. https://doi. org/10.1016/j.biombioe.2005.07.018

Solgi, A., Najafi, A., Sadeghi, S.H., 2014: Effects of traffic frequency and skid trail slope on surface runoff and sediment yield. International Journal of Forest Engineering 25(2): 171-178. https://doi.org/10.1080/14942119.2014.955699

Swift, L.W., Jr., 1985: Forest road design to minimize erosion in the southern Appalachians. In Proc. Forestry and Water Quality: A Mid-South Symposium,. B. G. Blackmon (ed.), University of Arkansas, Monticello, Arkansas, USA, 141151.

Swift, L.W., Jr., Burns, R.G., 1999: The three Rs of roads. Journal of Forestry 97(8), 40-44. https://doi.org/10.1093/jof/97.8.40

Wade, C.R., Bolding, M.C., Aust, W.M., Lakel, W.A., 2012: Comparison of five erosion control techniques for bladed skid trails in Virginia. Southern Journal of Applied Forestry 36(4): 191-197. https://doi.org/10.5849/sjaf.11-014

Wallbrink, P.J., Croke, G., 2002: A combined rainfall simulator and tracer approach to assess the role of Best Management Practices in minimising sediment redistribution and loss in forests after harvesting. Forest Ecology and Management 170(1): 217-232. https://doi.org/10.1016/S03781127(01)00765-4

Wischmeier, W.H., Smith, D.D., 1958: Rainfall energy and its relationship to soil loss. Transactions American Geophysical Union 39(2): 285-291. https://doi.org/10.1029/ TR039i002p00285

(C) 2018 by the authors. Submitted for possible open access publication under the terms and conditions of the Creative Commons Attribution (CC BY) license (http://creativecommons.org/licenses/by/4.0/). 
Authors' addresses:

Ahmad Solgi, $\mathrm{PhD}$ *

e-mail: solgi_ahmad231@yahoo.com

Prof. Ramin Naghdi, PhD

e-mail: rnaghdi@guilan.ac.ir

University of Guilan

Faculty of Natural Resources

Department of Forestry

Sowmeh Sara, Guilan

P.O. Box 1144

IRAN

Assist. prof. Eric R. Labelle, PhD

e-mail: eric.labelle@tum.de

Department of Ecology and Ecosystem Management

Technical University of Munich

Hans-Carl-von-Carlowitz-Platz 2

85354 Freising

GERMANY

Assoc. prof. Farshad Keivan Behjou, PhD

e-mail: farshad.keivan@gmail.com

University of Mohaghegh Ardabili

Department of Natural Resources

Ardabil

IRAN

Assist. prof. Vahid Hemmati, PhD

e-mail: vahidhemmatiliau@gmail.com

Islamic Azad University

Lahijan Branch

IRAN

* Corresponding author 